\title{
A Distinctive Culture? The Sources of Public Support for Immigration in Canada, 1980-2019 - CORRIGENDUM
}

Keith Banting ${ }^{1}$ and Stuart Soroka ${ }^{2}$

${ }^{1}$ Department of Political Studies, Queen's University, Mackintosh-Corry Hall, 68 University Ave, Kingston, ON K7L 3N6, Canada and ${ }^{2}$ Department of Communication and Media, University of Michigan, North Quad, 105 South State Street, Ann Arbor, MI 48109-1285, USA

https://doi.org/10.1017/S0008423920000530, published by Cambridge University Press, 27 July 2020.

Keywords: immigration; public opinion; political behaviour; corrigendum

Mots-clés : immigration; opinion publique; comportements politiques; corrigendum In the original publication of this article, the date range provided in the article's title did not reflect the updated range of the study data.

The original article has been corrected. The authors apologize for this error.

\section{Reference}

Banting, Keith, and Stuart Soroka. 2020. "A Distinctive Culture? The Sources of Public Support for Immigration in Canada, 1980-2019." Canadian Journal of Political Science. Advance online publication. https://doi.org/10.1017/S0008423920000530

\footnotetext{
Cite this article: Banting K, Soroka S (2020). A Distinctive Culture? The Sources of Public Support for Immigration in Canada, 1980-2019 - CORRIGENDUM. Canadian Journal of Political Science 53, 920-920. https://doi.org/10.1017/S0008423920000827

(c) Canadian Political Science Association (l’Association canadienne de science politique) and/et la Société québécoise de science politique 2020
} 